\title{
PEMBERIAN EKSTRAK MENIRAN (Phyllanthus niruri Linn) TERHADAP GAMBARAN HISTOPATOLOGI INFUNDIBULUM AYAM PETELUR YANG DIINFEKSI Escherichia coli
}

\section{THE EFFECT OF MENIRAN (Phyllanthus niruri Linn) EXTRACT ON INFUNDIBULUM HISTOPATHOLOGICAL APPEARANCE OF LAYER CHICKEN INDUCED BY Eschericia coli}

\author{
Adinda Riezki Irawan 1), Emy Koestanti Sabdoningrum 2), Sri Hidanah 2), \\ Sri Chusniati 2), Sri Pantja Madyawati 2), Benjamin C. Tehupuring ${ }^{2)}$ \\ 1) Mahasiswa, 2) Dosen \\ Fakultas Kedokteran Hewan Universitas Airlangga \\ Kampus C UNAIR, Jl. Mulyorejo-Surabaya 60115 \\ Telp. 031-5992785, Fax. 031-5993015 \\ Email: jbmvunair@gmail.com
}

\begin{abstract}
The purpose of this research aimed to prove the effect of meniran extract (Phyllanthus niruri Linn) on layer hen infected with Escherichia coli to reduce inflammation and congestion on infundibulum histopathological view. This research used 20 samples of layer hen. The treatment in this research was P0- (not infected with Esherichia coli and did not treated with meniran(Phyllanthus niruri Linn)), P0+ (infected with Escherichia coli and did not treated with meniran(Phyllanthus niruri Linn)), P1 (infected with Escherichia coli and treated with 10\% meniran extract (Phyllanthus niruri Linn)), P2 (infected with Escherichia coli and treated with 20\% meniran extract (Phyllanthus niruri Linn)), P3 (infected with Escherichia coli and treated with 30\% meniran extract (Phyllanthus niruri Linn)). The data of this study analyzed by Kruskal-wallis and followed with Mann-withney test. The result of this research can be concluded that $10 \%$ concentration of meniran extract (Phyllanthus niruri Linn) was effective to eliminate Escherichia coli, 20\% concentration of meniran extract (Phyllanthus niruri Linn) able to promote antibacterial activity, and $30 \%$ concentration of meniran extract shown antibacterial rate on high potential so it can be used to reduce inflammation and congestion as the result of Escherichia coli infection.
\end{abstract}

Key words: Meniran Extract, Phyllanthus niruri Linn, Escherichia coli, Infundibulum, Laying Hens

\section{PENDAHULUAN}

Usaha ternak ayam petelur untuk saat ini dan yang akan datang cukup menjanjikan karena seiring dengan pertambahan jumlah penduduk, permintaan akan telur semakin bertambah (Pramudyawati dan Prabowo, 2009). Ayam petelur dapat menghasilkan telur antara 250 sampai 280 butir per tahun, bahkan untuk jenis Leghorn dapat mencapai 284-300 butir per tahun (Yuwanta, 2000). Kendala utama peternakan ayam petelur adalah penyakit ayam yang dapat menimbulkan kerugian. Colibacillosis merupakan salah satu penyakit yang paling sering menyerang unggas (Barnes et al., 2008). Colibacillosis adalah penyakit infeksius pada unggas yang disebabkan oleh bakteri Escherichia coli patogen, penyakit inimempunyai dampak yang penting dalam industri perunggasan, karena menyebabkan adanya gangguan pertumbuhan, penurunan produksi, peningkatan jumlah ayam afkir, penurunan kualitas karkas dan telur, penurunan daya tetas telur dan kualitas anak ayam, dan menyebabkan mudah terjadinya kompleks penyakit yang melibatkan sistem pernafasan, sistem pencernaan, 
atau sistem reproduksi yang sulit untuk ditanggulangi. Colibacillosis pada ayam petelur, sering dijumpai pada ayam dara atau dewasa, menjelang produksi maupun masa poduksi, dan menyebabkan kelainan pada alat reproduksi, berupa ovaritis dan salpingitis yang cenderung bersifat kronis (Tarmudji, 2003). Colibacillosis menyerang oviduk dalam kasus salpingitis, menyebabkan penurunan produksi telur, kualitas cangkang telur yang buruk dan penurunan kualitas internal yang terjadi pada penyakit infeksi. Telur tanpa cangkang atau dengan bentuk tidak normal, kerutan dan lipatan serta penipisan cangkang, atau albumen encer menunjukan kerusakan pada oviduk (Tahseen et al., 2016). Salpingitis terjadi akibat perpindahan bakteri Escherichia coli dari kloaka ke oviduk melalui kantung udara (air sacculitis). Salpingitis yang terjadi akibat perpindahan bakteri Escherichia coli melalui kantung udara banyak terjadi pada ayam umur muda dan merupakan infeksi sistemik (Adnan, 2011). Hasil nekropsi oviduk tampak penuh dengan eksudat dari lapisan albumin telur, pada mukosa terdapat cairan kental dan kongesti (Srinivasan $e t$ al., 2014). Diagnosis dan pengendalian yang tidak tepat pada colibacillosis menyebabkan timbulnya resistensi terhadap antibiotik yang digunakan. Penggunaan antibiotikdi dalam pengobatan selain harganya mahal dapat berdampak negatif terutama pada kesehatan akibat adanya residu pada produk hasil ternak yang dihasilkan dan tidak aman jika dikonsumsi dapat menyebabkan gangguan kesehatan. Penggunaan antibiotik yang kurang tepat dapat merugikan, menyebabkan bakteri menjadi resisten sehingga pengobatan yang diberikan kurang efektif (Widhyari, 2009).

Secara in vitro penelitian Noorhamdani dkk. (2009) membuktikan bahwa ekstrak meniran (Phyllanthus niruri Linn) memiliki efek antibakteri terhadap Escherichia coli. Zat aktif dalam meniran (Phyllanthus niruri Linn) berperan untuk meminimalisir perdarahan (Mathivanan et al., 2006). Meniran (Phyllanthus niruri Linn) dapat menghambat dan membunuh pertumbuhan bakteri Escherichia coli karena zat-zat yang terkandung berfungsi sebagai antibakteri seperti alkaloid, tannin, saponin, dan flavonoid (Suwarni, 2001). Alkaloid bekerja sebagai antibakteri dengan cara mengganggu komponen penyusun peptidoglikan pada sel bakteri, sehingga lapisan dinding sel bakteri tidak terbentuk secara utuh dan menyebabkan kematian (Monalisa dkk., 2011). Tanin berkhasiat sebagai antiseptik dan hemostatik (Mathivanan et al., 2006). Flavonoid berkhasiat sebagai antioksidan dan anti karsinogenik, pada meniran (Phyllanthus niruri Linn) flavonoid memiliki potensi sebagai imunomodulator, sehingga mampu meningkatkan sistem kekebalan tubuh, dan mampu menangkal serangan virus, bakteri, atau mikroba lainnya (Suhirman dan Winarti, 2010).

\section{METODE PENELITIAN}

\section{TEMPAT DAN WAKTU PENELITIAN}

Penelitian ini dilaksanakan di peternakan ayam layer desa Ngrejo kabupaten Blitar.Perbanyakan bakteri Escherichia coli di Laboratorium Bakteriologi dan Mikologi Departemen Mikrobiologi Fakultas Kedokteran Hewan Universitas Airlangga. Pembuatan preparat histopatologi di Laboratorium Patologi Departemen Patologi Veteriner Fakultas Kedokteran Hewan Universitas Airlangga, serta untuk melakukan ekstraksi meniran di Laboratorium Farmakologi Departemen Ilmu Kedokteran Dasar Veteriner Fakultas Kedokteran Hewan Universitas Airlangga. Penelitian ini dilakukan selama 3 bulan mulai dari bulan Maret Mei 2018. 
PROSEDUR PENELITIAN

PERBANYAKAN BAKTERI E. Coli

Bakteri Escherichia coli ditumbuhkan di media EMBA dibuat suspense dan diencerkan berdasarkan standart Mc Farland I (suspense mengandung $3 \times 10^{8} \mathrm{CFU} / \mathrm{ml}$ ) (Oliveira et al., 2008).

\section{PENENTUAN DOSIS}

Ayam petelur diinfeksi dengan bakteri Eschericia coli secara intramuscular dengan konsentrasi $10^{8}$ sel/kgBB sebanyak $1 \mathrm{ml} / \mathrm{kgBB}$ kemudian diamati gejala klinis selama 3 hari. Ekstrak meniran diberikan pada hari ke 9 secara peroral dengan dosis yang berbeda setiap kelompok perlakuan yaitu dosis $10 \%, 20 \%$, dan $30 \%$ (Mahindra, 2014) selama 5 hari.

\section{PERLAKUAN}

P0 (-) : kelompok ayam petelur yang tidak diberikan perlakuan apapun (kontrol negatif).

P0 (+) : kelompok ayam petelur yang tidak diberikan ekstrak meniran (Phylantus niruri Linn) tapi diinfeksi Eschericia coli konsentrasi $10^{8} \mathrm{sel} / \mathrm{kgBB}$ sebanyak $1 \mathrm{ml} / \mathrm{kgBB}$

P1 : kelompok ayam petelur yang diinfeksi Eschericia coli konsentrasi $10^{8}$ sel/kgBBsebanyak $\mathrm{ml} / \mathrm{kgBB}$, kemudian diberi ekstrak meniran (Phylantus niruri Linn) 10\% sebanyak 1 $\mathrm{ml} / \mathrm{kgBB}$

P2 : kelompok ayam petelur yang diinfeksi Eschericia coli konsentrasi $10^{8} \mathrm{sel} / \mathrm{kg} \mathrm{BB}$ sebanyak $1 \mathrm{ml} / \mathrm{kgBB}$, kemudian diberi ekstrak meniran (Phylantus niruri Linn) $\quad 20 \%$ sebanyak 1 $\mathrm{ml} / \mathrm{kgBB}$.
P (3) : kelompok ayam yang diinfeksi Eschericia coli konsentrasi $10^{8} \mathrm{sel} / \mathrm{kg} \quad \mathrm{BB}$ sebanyak $1 \mathrm{ml} / \mathrm{kg} \quad \mathrm{BB}$, kemudian diberi ekstrak meniran (Phylantus niruri Linn) $\quad 30 \%$ sebanyak 1 $\mathrm{ml} / \mathrm{kgBB}$

\section{PENGAMATAN HISTOLOGI HEPAR}

Pemeriksaan histopatologi
infundibulum dilakukan dengan
mengamati adanya radang dan
kongesti dengan menggunakan
mikroskop cahaya pada pembesaran
400x. Pengamatan dilakukan terhadap
lima lapangan pandang yang
berbedauntuk tiap preparat
histopatologi infundibulum dan
dilakukan skoring.

\section{ANALIS DATA}

Data yang diperoleh dari hasil skor gambaran patologi infundibulum dianalisa dengan uji Kruskall-Wallis dan bila terdapat perbedaan yang nyata diantara kelompok perlakuan $(\mathrm{p}<0,05)$, maka dilanjutkan dengan uji MannWhitney (Daniel, 1991). Data disajikan dalam bentuk nilai median. Analisis statistika dilakukan dengan menggunakan program SPSS for Windows 20.

\section{HASIL DAN PEMBAHASAN}

Berdasarkan hasil pengamatan mikroskopis, didapatkan hasil analisis statistik untuk radang dan kongesti sebagai berikut: 
Tabel 4.1 Nilai Median Skor Radang Infundibulum Ayam Petelur

\begin{tabular}{|c|c|}
\hline Perlakuan & Nilai Median \\
\hline P0- & $1,00^{\mathrm{a}}$ \\
\hline P0+ & $4,00^{\mathrm{b}}$ \\
\hline P1 & $1,00^{\mathrm{b}}$ \\
\hline P2 & $1,00^{\mathrm{ab}}$ \\
\hline P3 & $0^{\mathrm{a}}$ \\
\hline
\end{tabular}

Keterangan: Superskrip yang berbeda pada kolom yang sama menunjukan perbedaan yang nyata.

Berdasarkan hasil analisis statistik untuk radang infundibulum dengan uji Kruskal-Wallis menunjukkan bahwa terdapat hasil yang berbeda nyata $(\mathrm{p}<0,05)$. Pada uji Mann-Whitney didapatkan P0- tidak berbeda nyata dengan P2 dan P3 tetapi berbeda nyata dengan $\mathrm{PO}+$ dan $\mathrm{P} 1 . \mathrm{P} 0+$ tidak berbeda nyata dengan $\mathrm{P} 1$ dan $\mathrm{P} 2$ tetapi berbeda nyata dengan P0- dan P3. P1 tidak berbeda nyata dengan $\mathrm{P}+$ dan $\mathrm{P} 2$ tetapi berbeda nyata dengan PO- dan P3. P2 tidak berbeda nyata dengan $\mathrm{P} 0-, \mathrm{P}+$ dan P1 tetapi berbeda nyata dengan P3. P3 tidak berbeda nyata dengan $\mathrm{P} 0$ - tetapi berbeda nyata dengan PO+, P1 dan P2.

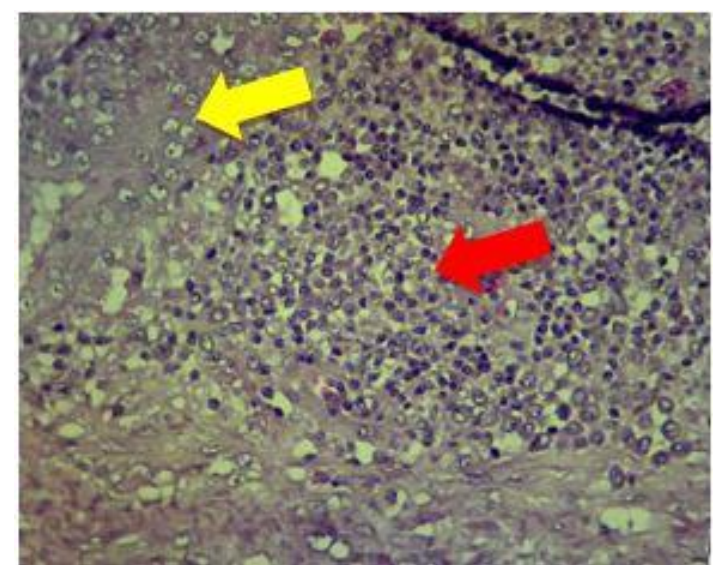

Gambar 4.1 Gambaran histopatologi radang pada infundibulum ayam petelur, dapat dilihat pada panah merah sel radang, panah kuning inti sel kelenjar tubular (Pewarnaan H.E; perbesaran 400x; Mikroskop Olympus ${ }^{\circledR}$ CX-41).
Tabel 4.2 Nilai Median Skor Kongesti Infundibulum Ayam Petelur

\begin{tabular}{|c|c|}
\hline Perlakuan & Nilai Median \\
\hline P0- & $1,00^{\mathrm{a}}$ \\
\hline P0+ & $3,00^{\mathrm{a}}$ \\
\hline P1 & $1,00^{\mathrm{b}}$ \\
\hline P2 & $1,00^{\mathrm{ab}}$ \\
\hline P3 & $0^{\mathrm{a}}$ \\
\hline
\end{tabular}

Keterangan: Superskrip yang berbeda pada kolom yang sama menunjukan perbedaan yang nyata.

Berdasarkan hasil analisis statistik kongesti infundibulum dengan uji Kruskal-Wallis (lampiran 7) menunjukkan bahwa terdapat hasil yang berbeda nyata $(\mathrm{p}<0,05)$. Pada uji Mann-Whitney didapatkanP0+ berbeda nyata dengan P3 sedangkan untuk P0-, P1 dan P2 tidak berbeda nyata.

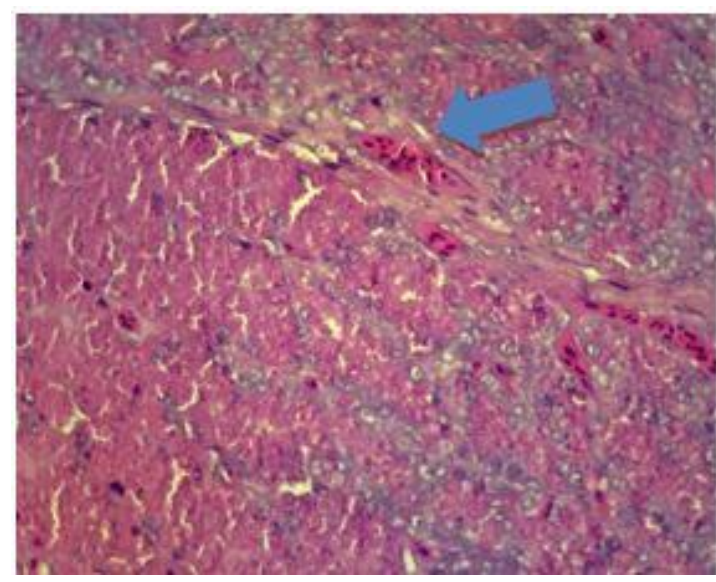

Gambar 4.1 Gambaran histopatologi kongesti pada infundibulum ayam petelur, dapat terlihat pada panah biru menunjukan adanya kongesti pada pembuluhdarah. (Pewarnaan H.E; perbesaran 400x; Mikroskop Olympus ${ }^{\circledR}$ CX-41

Berdasarkan hasil pemberian ekstrak meniran (Phyllanthus niruriLinn) terhadap gambaran histopatologi infundibulum ayam petelur yang diinfeksi Escherichia coli menunjukan hasil ekstrak meniran (Phyllanthus niruri Linn) dalam mengurangi terjadinya 
kerusakan fungsi infundibulum akibat infeksi Escherichia coli. Hasil skor histopatologis infundibulum meliputi kelainan patologi berupa radang dan kongesti. Tabel (4.1) dan tabel (4.2) menunjukkan bahwa semakin tinggi tingkat kerusakan yang ditimbulkan Escherichia coli, semakin tinggi pula skor yang dihasilkan. Hal ini menunjukan adanya aktivitas fagositosis sebagai reaksi perlawanan terhadap agen infeksi (Lohani, 2010).

Kelompok perlakuan $\mathrm{P0}(-)$ yaitu tanpa diinfeksi bakteri Escherichia coli dan tanpa diberikan ekstrak meniran (Phyllanthus niruriLinn), kondisi infundibulum normal karena sel infundibulum tidak radang dan kongesti. Kelompok perlakuan $\mathrm{P0}(+)$ yang tanpa diberikan ekstrak meniran (Phyllanthus niruriLinn) namun diinfeksi bakteri Escherichia coli menunjukkan kelainan patologi berupa infiltrasi yaitu penyusupan atau masuknya sel radang (Darmawan dan Himawan, 1994) dengan skor 4 dibandingkan dengan kelompok yang lainnya. Pada gambaran histopatologi infundibulum PO (+), terlihat adanya infiltrasi sel radang berwarna keunguan (Sugihartini dan Fajri, 2016). Radang terjadi akibat adhesin yang dihasilkan Escherichia coli berupa fimbriae tipe I untuk kolonisasi akibatnya terjadi ciliatosis. Reseptor spesifik fimbrie I melalui interaksi dengan ligan mampu memacu respon kekebalan dengan hadirnya makrofag, mastosit, limfosit $b$ dan netrofil (Huang and Matsumoto 1999). Kelompok perlakuan P1 (dosis 10\%) juga menunjukkan adanya infiltrasi sel radang, namun tidak sebanyak perlakuan $\mathrm{PO}(+)$ yang diinfeksi Escherichia coli108 $\mathrm{CFU} / \mathrm{ml} / \mathrm{kgBB}$ tetapi tidak diberikan ekstrak meniran (Phyllanthus niruri Linn).

Pada kelompok perlakuan P2 dengan skor 1yang diberikan ekstrak meniran (Phyllanthus niruri Linn) dengan konsentrasi 20\% radang sudah nampak berkurang dari kelompok perlakuan sebelumnya. Kelompok perlakuan P3 yang diberikan ekstrak meniran (Phyllanthus niruriLinn) dengan konsentrasi $30 \%$ dengan skor 0 menunjukan bahwa sudah tidak terdapat radang. Peran ekstrak meniran (Phyllanthus niruriLinn) pada konsentrasi ini telah dapat mengurangi reaksi peradangan, dikarenakan keadaannya hampir mencapai normal, dalam artian semakin tinggi konsentrasi daya antibakteri ekstrak meniran (Phyllanthus niruriLinn) maka daya bunuh terhadap Escherichia coli semakin meningkat, dan semakin rendah konsentrasi daya antibakteri ekstrak meniran (Phyllanthus niruriLinn) daya bunuh terhadap Escherichia coli semakin rendah. Hal tersebut sesuai dengan pernyataan Jawetz et al. (1996), Volk and Wheller (1993) bahwa daya antibakteri ditentukan oleh konsentrasi. Sidik dan Subarnas, 1993 menyatakan semakin tinggi konsentrasi zat antibakteri tersebut, maka semakin paten pula kemampuannya bekerja sebagai bakteriosid.

Pada kelompok $\mathrm{P} 0(+)$ mengalami kongesti paling parah dengan skor 3 , tampak mikrosirkulasi melebar/dilatasi dan penuh eritrosit (Arimbi dkk., 2014). Pada kongesti post mortem kadang akan mengosongkan vena (Arimbi dkk., 2014). Pada kelompok perlakuan P0(-), P1 dan P2 masih terlihat adanya kongesti, tetapi dalam jumlah yang sedikit, sehingga skor yang didapat adalah 1. Pada kelompok perlakuan P3 tidak ditemukan adanya kongesti, hal tersebut dikarenakan peran ekstrak tanaman meniran (Phyllanthus niruriLinn) dengan konsentrasi 30\% telah dapat mengurangi kongesti. Kongesti terjadi akibat adanya inflamasi disebabkan stres oksidatif karena tidak adanya keseimbangan antara produksi oksidan dan antioksidan defence (Febriana, 2016). Flavanoid bersifat antithrombik dapat membentuk sumbat thrombosit, sehingga dapat menutup robekan kecil pada pembuluh darah, 
menghambat perkembangan bakteri dengan bertindak sebagai inhibitor enzim dengan cara menghambat produksi energi dan asam nukleat atau protein serta dapat menurunkan permiabilitas kapiler darah, sehingga kerusakan kapiler darah dapat dicegah atau dapat diperbaiki. Tanin berkhasiat sebagai antiseptik (mencegah pertumbuhan bakteri) dan hemostatik (menghentikan perdarahan) (Mathivanan et al., 2006).

Hasil penelitian menunjukkan terdapat perbedaan nyata antara $\mathrm{PO}(+)$ dengan P0(-), P1, P2, dan P3. Pada P0(+) mengalami kongesti paling parah dikarenakan pada kelompok perlakuan tersebut hanya diinfeksi bakteri Escherichia coli dan tanpa diberikan ekstrak meniran (Phyllanthus niruriLinn). Berdasarkan hasil penelitian dapat diketahui bahwa ekstrak meniran (Phyllanthus niruriLinn) konsentrasi 10\% (P1) sudah mampu membunuh Escherichia coli, pada konsentrasi ekstrak meniran (Phyllanthus niruriLinn)20\% terjadi peningkatan aktivitas antibakteri terhadap bakteri Escherichia coli. Pada konsentrasi ekstrak meniran (Phyllanthus niruriLinn) $30 \% \quad$ (P3) menunjukkan daya antibakteri yang tinggi potensinya sehingga dapat mengurangi terjadinya radang dan kongesti akibat infeksi bakteri Escherichia coli.

\section{KESIMPULAN}

Berdasarkan hasil penelitian ini dapat diambil kesimpulan bahwa pemberian ekstrak meniran (Phyllanthus niruri Linn) padaayampeteluryang diinfeksi Escherichia coli dapat menurunkan radang dan kongesti pada gambaran histopatologi infundibulum. Ekstrak meniran (Phyllanthus niruri Linn) dengan konsentrasi $10 \%$ dapat mengurangi terjadinya radang dan kongesti.

\section{DAFTAR PUSTAKA}

Adnan, K. 2011. Kupas Penyakit Colibacillosis (Akibat Bakteri E. coli pada Ayam).

Arimbi., Azmijah, A., Darsono, A., Plumeriastuti, H., Widiyatno, T. H., dan Legowo, D. 2013. Buku Ajar Patologi Umum Veteriner. Airlangga University Press. Surabaya

Barnes, H. J., Lisa K. N., and Vaillancourt. J. P. 2008. Colibacillosis, p 691- 716 In Saif YM, editor. , Diseases of poultry, 12th ed. Iowa State University Press, Ames, IA.

Darmawan, S. dan Himawan. S. 1994. Patologi. Fakultas Kedokteran, Bagian Patologi Anatomi, Universitas Indonesia, Jakarta.

Febriana, H. I. 2016. Formulasi ‘Gel Tetrahidropentagamavunon-0 (THPGV-0) dan Uji Iritasi Akut Dermal pada Kelinci Serta Penentuan Nilai SPF Secara In Vitro', Skripsi, S. Farm., Universitas Gadjah Mada, Yogyakarta.

Jawetz, E., Melnick, J. L. dan Adelberg, E. A. 1996. Mikrobiologi Kedokteran. Edisi 20. Buku Kedokteran. Jakarta: ECG. 159160.Penerjemah Edi Nugroho dan R. F. Maulany, editor Irawati Setiawan.

$\begin{array}{llr}\text { Lohani, } & \text { M. } & 2010 . \\ \text { Immunomodulatory } & \\ \text { properties of noni } & \text { (Morinda } \\ \text { citrifolia). } & \text { Thesis. } & \text { Graduate } \\ \text { School of } & \text { Clemson } & \text { University, } \\ \text { USA } & & \end{array}$


Mahindra, A. 2014. Persamaan Potensi Antibakterial Ekstrak Meniran (Phyllanthus niruri L) dan Ciprofloxacin terhadap Escherichia coli Isolat Lapang secara Invitro. Skripsi Thesis, Universitas Airlangga.

Mathivanan, R., Edwin, S.C., Amutha,R. and Viswanathan,K. 2006. Panchagavya and Andrographis Panicuata as Alternative to Antibiotic Growth Promoter on Broiler Production and Carcass Characteristic. India. Departement of Poultry Science, Veterinary College and Research Institute. Namakkal-637001.

Monalisa, D., Handayani, T., dan Sukmawati, D. 2011. Uji Daya Antibakteri Ekstrak Daun Tapak Liman (Elephantopus scaber L.) Terhadap Staphylococcus aureus Dan Salmonella typhi. BIOMA. Vol. IX, No.2

Noorhamdani, A. S., Habiba, A.dan Airin, A. 2009. Uji Efektivitas Antimikroba Ekstrak Daun Meniran (Phyllanthus niruri) Terhadap Bakteri E. coli Secara In Vitro. Fakultas Kedokteran. Universitas Brawijaya

Oliveira, A., Sereno. R., Nicolau A. AndAzeredo, J. 2008. The influence of the mode of administration in the dissemination of three coliphages in chickens. * Research and Development Department, Controlvet, Segurança Alimentar S. A., Zona Industrial de Tondela, ZIM II, L 6, 3460-070 Tondela, Portugal; and $†$ Institute for Biotechnology and Bioengineering, Centre of Biological Engineering, Universidade do Minho, Campus de Gualtar, 4710-057 Braga, Portugal

Pramudyati, Y. S. dan Prabowo, A. 2009. Beternak Ayam Ras Petelur. Petunjuk Teknis.

Sidik dan Subarnas, A. 1993. Phyllanthus niruri L.; Kimia, Farmakologi dan Penggunaannya Dalam Obat Tradisional. Proseding Seminar Meniran dan Kedawung13-14 Agustus. Surabaya.

Srinivian, P., Balasubramaniam, G. A., Murthy, G. K. T. R., and Balachandran, P. 2014.

Prevalence and pathology of oviduct impaction in commercial white leghorn layer chicken in Namakkal region of India.

Sugihartini, N. dan Fajri, A. M. 2016. Gambaran Histopatologi Organ Hati dan Ginjal Mencit Balb/c setelah Pemberian Krim Ekstrak Teh Hijau (Camellia sinensis L.)

Suhirman, S. dan Winarti, C. 2010. Prospek dan Fungsi Tanaman Obat Sebagai Imunomodulator. Balai Penelitian Tanaman Obat dan Aromatik.

Suwarni, E. 2001. Daya Antibakteri Meniran (Phyllanthus niruri L) Terhadap Escherichia coli secara In Vitro. [Skripsi]

Tahseen, A., Oscar, J. and John, B. 2016. Avian Histopathology. 4th Edition. The American Association of Avian Pathologist.

Tarmudji. 2003. Kolibasilosis pada Ayam: Etiologi, Patologi dan Pengendaliannya. Wartoza Vol. 13 No. 2 
Adinda. dkk. Pemberian Ekstrak Meniran (Phyllanthus niruri Linn) Terhadap Gambaran Histopat

Widhyari, S.D. 2009. Efektifitas Pemberian Kombinasi Mineral Zink dan Herbal Sebagai Imunomodulator. Bogor: Jurnal llmu Pertanian Indonesia Vol. 14 No.1, hlm. 30-14

Volk, W.A. dan Wheeler, M. F. 1993. Mikrobiologi Dasar. Alih Bahasa Markham, Editor Soenartono, A. Edisi V. Jlid I. Jakarta: Penerbit Erlangga. 50.
Yuwanta, T. 2000. Potensi dan Kendala Pengembangan Ayam Kampung Ditinjau Dari Aspek Produksinya. Pidato Pengukuhan Jabatan Guru Besardalam Ilmu Produksi Ternak. Fakultas Peternakan. Universitas Gadjah Mada. Yogyakarta. 